INDONESIA ACCOUNTING JOURNAL

VOLUME 1, NUMBER 2, YEAR 2019

${ }^{1}$ Corresponding author

Jurusan Akuntansi

Fakultas Ekonomi dan Bisnis

Universitas Sam Ratulangi

Jl. Kampus UNSRAT

Manado, Indonesia, 95115

E-mail : Carolinalahiwu29@gmail.com

${ }^{2,3}$ Jurusan Akuntansi

Fakultas Ekonomi dan Bisnis

Universitas Sam Ratulangi

Jl. Kampus UNSRAT

Manado, Indonesia, 95115

Article info:

Received 9 December 2019

Accepted 9 December 2019

Available online 9 December 2019

Keywords: fixed assets; government accountimg standards; accrual based; government accounting standard; technical bulletin

JEL Classification: $\mathrm{H}_{83}, \mathrm{M} 41$

DOI: http://doi.org/10.3240o/iaj.26656

\section{Analisis perlakuan akuntansi aset tetap pada Badan Pengelola Keuangan dan Barang Milik Daerah Kota Manado 2}

\author{
Carolina ${ }^{1}$ \\ Hendrik Manossoh ${ }^{2}$ \\ Robert Lambey ${ }^{3}$
}

\begin{abstract}
The main task of government agencies is to provide services to the community whose quality can be improved by the use of fixed assets to achieve the duties and functions of government agencies. The presence of Government Regulation (PP) of the Republic of Indonesia Number 71 Year 2010 concerning Accrual Based Government Accounting Standards is the momentum of changes in Government Accounting Standards from previously cash-based to accruals, to accrual-based and have major implications for the treatment of assets where depreciation is taken into account in the valuation of fixed assets. The purpose of this research is to find out the accounting treatment of Fixed Assets that are applied to the Regional Finance and Asset Management Agency (BPK-AD) of Manado City in accordance with Government Regulation No. 71 of 2010 statement No. 07. The research method used in this study is qualitative research. The results showed that the recognition of fixed assets, measurement or valuation of fixed assets, and depreciation of assets in the BPK-AD Manado City are in accordance with SAP No. 07, as well as the Manado City BPK-AD in the management of regional assets following a separate regulation made by the Manado city BPK-AD namely the Technical Bulletin (Bultek) as a reference to regulate and adjust regional asset management in accordance with SAP No. 07.
\end{abstract}

\section{Pendahuluan}

Pemerintah dalam lingkup OPD (Organisasi Perangkat Daerah) memerlukan manajemen pengelolaan dalam memanfaatkan aset yang telah diperoleh, sehingga prinsip efisiensi, efektivitas, dan transparansi dapat terlaksana. Tugas utama instansi pemerintah adalah memberikan pelayanan kepada masyarakat yang kualitasnya dapat ditingkatkan dengan adanya pemanfaatan aset tetap untuk pencapaian tugas dan fungsi instansi pemerintah. Keandalan pengakuan, pengukuran dan pengungkapan aset tetap bergantung pada Standar Akuntansi Pemerintahan yang digunakan. Pemerintah telah melakukan perubahan terhadap Standar Akuntansi Pemerintahan sebagai upaya dalam memperbaiki pelaporan dan pertanggungjawaban keuangan kepada masyarakat, termasuk perbaikan pelaporan aset tetap pemerintahan. Kehadiran Peraturan Pemerintah (PP) Republik Indonesia Nomor 71 Tahun 2010 tentang Standar Akuntansi Pemerintahan Berbasis Akrual merupakan momentum perubahan Standar Akuntansi Pemerintahan dari yang sebelumnya berbasis kas menuju berbasis akrual, yang berimplikasi besar terhadap perlakuan aset dimana penyusutan diperhitungkan dalam penilaian aset tetap.

Perlakuan aset tetap yang berdasarkan Pernyataan Standar Akuntansi Pemerintahan nomor 7 tentang Aset Tetap adalah Standar yang mengatur tentangaset tetap dapat mengintegrasikan antara arus uang dan arus barang dengan menerapkan sistem pembukuan ganda (double entry). Ruang lingkup untuk pernyataan Standar Akuntansi 
Pemerintah nomor 7 diterapkan untuk seluruh unit pemerintahan yang menyajikan laporan keuangan dengan tujuan untuk mengatur tentang perlakuanakuntansi baik itu pengakuan, pengukuran atau pengungkapan yang digunakan; apakah akuntansi aset tetap yang dilaksanakan telah sesuai dengan standar yang ditetapkan pemerintah. Oleh karena itu, akuntansi berbasis akrual menyediakan informasi aset tetap yang wajar dalamrangka pengambilan keputusan dibandingkan akuntansi berbasis kas. Aset tetap yang dimiliki atau dikuasai oleh pemerintah harus dinilai atau diukur untuk dilaporkan dalam neraca yaitu pada kelompok aset tetap.

Badan Pengelola Keuangan dan Aset Daerah (BPK-AD) merupakan salah satu Satuan Kerja Perangkat Daerah (SKPD) yang ada di wilayah Pemerintahan Kota Manado yang mempunyai tugas pokok untuk membantu Walikota dalam mengelola keuangan dan barang milik daerah berdasarkan Peraturan Walikota Manado sebagai pelaksana anggaran. Sebagai pelaksana anggaran, Badan Pengelola Keuangan dan Aset Daerah (BPK-AD) Kota Manado harus membuat pertanggungjawaban atas kewenangan yang dilaksanakannya sesuai dengan Peraturan Pemerintah Nomor 71 Tahun 2010. Badan Pengelola Keuangan dan Aset Daerah (BPK-AD) Kota Manado memiliki aset tetap yang dipergunakan dalam menunjang kegiatan pemerintah. Berdasarkan hal tersebut maka sangat diperlukan pengelolaan yang baik atas aset tetap yang dimiliki daerah kota Manado.

\section{Tinjauan pustaka}

Akuntansi. Menurut Kieso, et al (2016:2), akuntansi terdiri dari tiga kegiatan yang mendasar yaitu identifikasi, pencatatan, dan pengkomunikasikan peristiwa ekonomi suatu organisasi kepada pihak yang berkepentingan.

Akuntansi Sektor Publik. Menurut Mahsun (2013:5), menyatakan bahwa akuntansi sektor publik seringkali dipahami sebagai segala sesuatu yang berhubungan dengan kepentingan umum dan penyediaan barang atau jasa kepada publik yang dibayar melalui pajak atau pendapatan negara lain yang di atur dengan hukum, dan akuntansi sektor publik merupakan salah satu bidang ilmu yang perkembangannya sangat pesat dalam beberapa tahun terakhir.

Pemerintah Daerah. Permendagri No.19 Tahun 2016, menyatakan bahwa pemerintahan daerah adalah penyelenggaraan urusan pemerintahan oleh pemerintah daerah dan dewan perwakilan rakyat daerah menurut asas otonomi dan tugas pembantuan dengan prinsip otonomi seluas-luasnya dalam sistem dan prinsip Negara kesatuan Republik Indonesia sebagaimana dimaksud dalam UUD Tahun 1945.

Standar Akuntansi Pemerintahan. Menurut PSAP 07, Standar akuntansi pemerintahan adalah prinsip-prinsip akuntansi yang diterapkan dalam menyusun dan menyajikan laporan keuangan pemerintah.

Sistem Akuntansi Pemerintah Daerah. Peraturan Pemerintah Nomor 58 Tahun 2005 Pasal 96 tentang Akuntansi Keuangan Daerah, pemerintahan daerah berkewajiban menyusun sistem akuntansi pemerintahan daerah dengan mengacu pada Standar Akuntansi Pemerintahan (SAP). Sistem akuntansi pemerintahan daerah tersebut ditetapkan dengan peraturan kepala daerah yang mengacu pada Peraturan Daerah tentang Pengelolaan Keuangan Daerah.

Sistem Akuntansi SKPD. Menurut Tanjung (2013:160) Satuan Kerja Perangkat Daerah (SKPD) merupakan entitas akuntansi dan harus melaksanakan sistem akuntansi pemerintahan daerah pada tingkat SKPD diistilahkan dengan sistem akuntansi SKPD. Sistem akuntansi SKPD ini dilaksanakah oleh PPK, SKPD, akuntansi realisasi belanja SKPD merupakan bagian dari sistem akuntansi SKPD tersebut.

Aset Tetap. Nordiawan dkk, (2012:229) menyatakan bawah aset tetap adalah aset berwujud yang mempunyai masa manfaat lebih dari 12 bulan untuk digunakan dalam kegiatan pemerintahan atau dimanfaatkan oleh masyarakat umum. 
Pengakuan Aset Tetap. Halim \& Kusufi (2103:119), menyatakan bahwa aset tetap diakui pada saat potensi manfaat ekonomi masa depan dapat diperoleh pemerintah dan mempunyai nilai yang dapat diukur dengan handal.

Pengukuruan Aset Tetap. Halim \& Kusufi (2013:120), menyatakan bahwa aset tetap dicatat sebesar beban perolehan. Apabila penilaian aset tetap dengan menggunakan biaya perolehan tidak memungkinkan maka nilai aset tetap didasarkan pada nilai wajar pada saat perolehan.

Pengungkapan. Menurut PSAP 07, Pengungkapan disajikan pada lembar muka neraca, aset tetap juga harus diungkapkan dalam Catatan atas Laporan Keuangan (CaLK). Dalam Catatan atas Laporan Keuangan harus diungkapkan untuk masingmasing jenis aset tetap sebagai berikut :

- Dasar penilaian yang digunakan untuk menentukan nilai tercatat.

- Rekonsiliasi jumlah tercatat pada awal dan akhir periode yang menunjukkan: (a) penambahan; (b) pelepasan; (c) akumulasi penyusutan dan perubahan nilai jika ada; dan (d) mutasi aset tetap lainnya.

- Informasi penyusutan, meliputi: (a) nilai penyusutan; (b) metode penyusutan yang digunakan; (c) masa manfaat atau tarif penyusutan yang digunakan; (d) nilai tercatat bruto dan akumulasi penyusutan pada awal dan akhir periode.

Selain itu, dalam Catatan atas Laporan Keuangan juga harus diungkapkan: (1) eksistensi dan batasan hak milik ata aset tetap; (2) kebijakan akuntansi untuk kapitalisasi yang berkaitan dengan aset tetap; (3) jumlah pengeluaran pada pos aset tetap dalam konstruksi; dan (4) jumlah komitmen untuk akuisisi aset tetapjika pengelolaannya buruk maka akan berdampak buruk pula pada pemerintahan yang ada.

Penyusutan. Menurut Surya (2012:173), Penyusutan adalah alokasi jumlah yang dapat disusutkan dari suatu aset sepanjang masa manfaat yang estimasi. Jumlah yang dapat disusutkan dari suatu aset adalah biaya yang dikeluarkan untuk memperoleh aset tersebut dikurangi dengan estimasi nilai sisa (savage value) aset tersebut pada akhirnya masa manfaat.

Penelitian Terdahulu. Masipuang et al (2015) dalam penelitian yang berjudul Analisis Perlakuan Akuntansi Aset Tetap Pada Badan Kepegawaian Dan Diklat (BKD) Kota Manado telah sesuai dengan PP 71 Tahun 2010. Hariadi et al (2018) dalam penelitian yang berjudul Evaluasi penerapan perlakuan akuntansi terhadap aktiva tetap berdasarkan PSAK No. 16 pada PT. Pegadaian (PERSERO) Cabang Malalayang Manado sudah baik dan benar mengacu pada Standar Akuntansi Keuangan yang berlaku. Putra (2013) dalam penelitian yang berjudul Analisis Penerapan Akuntansi Aset Tetap Pada CV. Kombos Manado sudah mendakati Pernyataan Standar Akuntansi Keuagan (PSAK) No. 16.

\section{Metode penelitian}

Jenis Penelitian. Jenis penelitian yang digunakan dalam penelitian ini adalah penelitian kualitatif. Tempat dan waktu penelitian Penelitian ini dilaksanakan di Badan Pengelola Keuangan dan Aset Daerah Kota Manado yang beralamat di Jl. Balai Kota No.1 Tikala, Kota Manado, Sulawesi Utara. Waktu penelitian dilakukan selama bulan November 2018 sampai selesai.

Metode Pengumpulan Data. Metode yang digunakan dalam penelitian ini adalah studi lapangan. Metode ini digunkan untuk mengetahui seberapa jauh kesesuaian antara teori yang digunakan dengan keadaan yang sebenarnya dari objek yang diteliti. Dalam studi lapangan ini peneliti menggunakan teknik pengumpulan data, yaitu survei pendahuluan.

Metode Analisis. Sugiyono (2009:21) menyatakan bahwa metode analisis adalah metode yang digunakan untuk menggambarkan dan menganalisis suatu hasil penelitian tetapi tidak digunakan untuk membuat kesimpulan yang lebih luas. Metode yang digunakan oleh peneliti dalam penelitian ini adalah metode analisis deskriptif.Data dan informasi yang 
dikumpulkan akan dianalisis dengan menggunakan metode deskriptif yaitu dengan cara membandingkan kesesuaian antara perlakuan akuntansi dalam Satuan Kerja Perangkat Daerah (SKPD) dan Peraturan Pemerintah tentang Standar Akuntansi Pemerintahan.

\section{Hasil penelitian dan pembahasan \\ Hasil Penelitian}

Akuntansi Tanah. Berdasarkan hasil wawancara dengan Bapak Mekson Waney, SE, MSA selaku KASUBID Mutasi dan Pelaporan Aset mengatakan bahwa dalam hal pengakuan tanah dimana BPK-AD Kota Manado mengacu pada Buletin Teknis yang dijadikan acuan, Tanah dapat diakui sebagai aset tetap apabila memenuhi 4 (empat) kriteria berikut: (1) mempunyai masa manfaat lebih dari 12 (dua belas) bulan; (2) perolehan aset dapat diukur secara andal; (3) tidak dimaksudkan untuk dijual, dan (4) diperoleh dengan maksud untuk digunakan. Apabila salah satu kriteria tidak terpenuhi maka tanah tersebut tidak dapat diakui sebagai aset tetap milik pemerintah. Pengadaan tanah pemerintah yang sejak semula dimaksudkan untuk diserahkan kepada pihak lain tidak disajikan sebagai aset tetap tanah, melainkan disajikan sebagai persediaan. Pengukuran suatu aset tetap harus memperhatikan kebijakan pemerintah mengenai ketentuan nilai satuan minimum kapitalisasi aset tetap. Namun, untuk aset tetap berupa tanah, berapapun nilai perolehannya seluruhnya dikapitalisasi sebagai nilai tanah. Aset tetap tanah disajikan dalam neraca sesuai dengan biaya perolehan. penyajian dan pengungkapan tanah mengikuti pedoman Bultek dimana tanah disajikan di neraca dalam kelompok aset tetap sebesar biaya perolehan atau nilai wajar pada saat aset tanah diperoleh.

Peralatan dan Mesin. Berdasarkan wawancara dengan Bapak Mekson Waney mengatakan mengacu pada pedoman Bultek dimana pada BPK-AD Manado pengakuan peralatan dan mesin dapat dilakukan apabila terdapat bukti bahwa hak/kepemilikan telah berpindah, misalnya ditandai dengan berita acara serah terima pekerjaan, dan untuk kendaraan bermotor dilengkapi dengan bukti kepemilikan kendaraan. Pengukuran peralatan dan mesin biaya perolehan atau nilai wajar pada asset tetap tersebut diperoleh. Biaya perolehan peralatan dan mesin menggambarkan jumlah pengeluaran yang telah dilakukan untuk memperoleh peralatan dan mesin tersebut sampai siap pakai. Biaya ini antara lain meliputi harga pembelian, biaya pengangkutan, biaya instalasi, serta biaya langsung lainnya untuk memperoleh dan mempersiapkan sampai peralatan dan mesin tersebut siap digunakan. Dalam Penyajian dan Pengungkapan Peralatan dan Mesin disajikan di Neraca dalam kelompok Aset Tetap sebesar biaya perolehannya atau nilai wajar pada saat perolehan.

Akuntansi Gedung dan Bangunan. Dari wawancara dengan Bapak Mekson Waney menyatakan untuk dapat diakui sebagai Gedung dan Bangunan, maka Gedung dan bangunan itu harus berwujud dan mempunyai masa manfaat lebih dari 12 (dua belas) bulan, biaya perolehannya dapat diukur secara handal, tidak dimaksudkan untuk dijual dalam kondisi normal entitas dan diperoleh atau dibangun dengan maksud untuk digunakan. Pengukuran Gedung dan Bangunan harus memperhatikan kebijakan pemerintah mengenai ketentuan nilai satuan minimum kapitalisasi aset tetap gedung dan Bangunan disajikan di Neraca dalam kelompok Aset Tetap sebesar nilai biaya perolehannya atau nilai wajar pada saat perolehan.

Akuntansi Jalan, Irigasi dan Jaringan. Berdasarkan melalui wawancara dengan Bapak Mekson Waney mengatakan jalan, irigasi, dan jaringan diakui pada saat jalan, irigasi, dan jaringan telah diterima atau diserahkan hak kepemilikannya dan/atau pada saat penguasaannya berpindah serta telah siap dipakai. Perolehan jalan, irigasi, dan jaringan pada umumnya dengan pembangunan baik membangun sendiri (swakelola) maupun melalui kontrak konstruksi. Biaya perolehan untuk jalan, irigasi dan jaringan yang diperoleh melalui kontrak yang meliputi biaya perencanaan 
dan pengawasan, biaya perizinan, jasa konsultan, biaya pengosongan, pajak, kontrak konstruksi, dan pembongkaran.

Akuntansi Aset Tetap Lainnya. Berdasarkan hasil wawancara dengan Bapak Mekson Waney, di BPK-AD Kota Manado Aset Tetap Lainnya diakui pada saat Aset Tetap Lainnya telah diterima atau diserahkan hak kepemilikannya dan/atau pada saat penguasaannya berpindah serta telah siap dipakai. Pengukuran Aset Tetap Lainnya harus memperhatikan kebijakan pemerintah tentang ketentuan nilai satuan minimum kapitalisasi aset tetap.penerapan di BPK-AD Manado Aset Tetap Lainnya yang dikapitalisasi dibukukan dan dilaporkan di dalam Neraca dan Laporan BMN/D. Aset Tetap Lainnya yang tidak dikapitalisasi tidak dapat diakui dan disajikan sebagai aset tetap, namun tetap diungkapkan dalam Catatan Atas Laporan Keuangan dan dalam Laporan BMN/D. Dalam aset tetap lainnya disajikan di neraca dalam kelompok Aset Tetap sebesar biaya perolehan atau nilai wajar pada saat perolehan.

Akuntansi Konstruksi Dalam Pengerjaanya. Melalui wawancara dengan Bapak Mekson Waney mengatakan apabila dalam konstruksi aset tetap pembangunan fisik proyek belum dilaksanakan, namun biaya-biaya yang dapat diatribusikan langsung ke dalam pembangunan proyek telah dikeluarkan, maka biaya-biaya tersebut harus diakui sebagai KDP aset yang bersangkutan. Dokumen sumber untuk pengakuan penyelesaian suatu KDP adalah Berita Acara Penyelesaian Pekerjaan(BAPP). Dengan demikian, apabila atas suatu KDP telah diterbitkan BAPP, berartipembangunan tersebut telah selesai. Selanjutnya, aset tetap definitif sudah dapat diakui dengan cara memindahkan KDP tersebut ke akun aset tetap yang bersangkutan.

\section{Pembahasan}

Tabel 1 perbandingan Pengakuan Aset Tetap oleh BPKAD Kota Manado dengan PSAP No. 07.
Tabel 1. Perbandingan Pengakuan Aset Tetap oleh BPKAD Kota Manado dengan PSAP No. 07

\begin{tabular}{|c|c|c|}
\hline PSAP Nomor 07 & BPKAD Kota Manado & Keterangan \\
\hline $\begin{array}{l}\text { a. Masa manfaat lebih } \\
\text { dari } 12 \text { (dua belas) } \\
\text { bulan. }\end{array}$ & 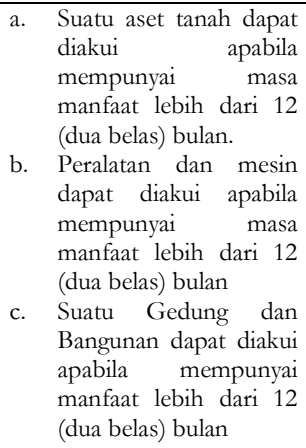 & Sesuai \\
\hline $\begin{array}{l}\text { b. Biaya perolehan } \\
\text { dapat diukur secara } \\
\text { andal. }\end{array}$ & $\begin{array}{l}\text { a. Biaya perolehan tanah } \\
\text { dapat diukur secara } \\
\text { handal } \\
\text { b. Biaya perolehan aset } \\
\text { peralatan dan mesin } \\
\text { dapat diukur secara } \\
\text { handal } \\
\text { c. Biaya peroleh gedung } \\
\text { dan bangunan dapat } \\
\text { diukur secara handal }\end{array}$ & Sesuai \\
\hline $\begin{array}{lr}\text { c. Diperoleh } & \text { atau } \\
\text { dibangun } & \text { dengan } \\
\text { maksud } & \text { untuk } \\
\text { digunakan. } & \end{array}$ & $\begin{array}{llr}\text { a. } & \text { Pengadaan tanah } \\
\text { pemerintah diperoleh } \\
\text { untuk dapat digunakan } \\
\text { b. Peralatan dan mesin } \\
\text { yang diperoleh dan } \\
\text { yang dimaksudkan akan } \\
\text { diserahkan kepada } \\
\text { pihak lain untuk dapat } \\
\text { digunakan } \\
\text { c. Gedung dan bangunan } \\
\text { yang rongun } \\
\text { pemerintah namun } \\
\text { dengan raksud } \\
\text { diserahkan kepada } \\
\text { masyarakat untuk dapat } \\
\text { digunakan }\end{array}$ & Sesuai \\
\hline $\begin{array}{l}\text { d. Pengakuan aset } \\
\text { tetap akan sangat } \\
\text { andal apabila aset } \\
\text { tetap telah diterima } \\
\text { atau diserahkan hak } \\
\text { kepemilikannya } \\
\text { pada saat } \\
\text { penguasaannya } \\
\text { berpindah. }\end{array}$ & $\begin{array}{l}\text { a. Pengakuan aset tetap } \\
\text { tanah akan lebih sangat } \\
\text { andal apabila bukti aset } \\
\text { tetap telah diterima } \\
\text { atau diserahkan hak } \\
\text { kepemilikanya atau } \\
\text { pada penguasaannya } \\
\text { berpindah peralatan } \\
\text { b. Pengakuan dapat } \\
\text { dan mesin apabila } \\
\text { dilakukan bahwa } \\
\text { terdapat bukti bahwa } \\
\text { hak/kepemilkannya } \\
\text { telah berpindah. } \\
\text { Saat pengakuan } \\
\text { Gedung dan bangunan } \\
\text { akan lebih dapat } \\
\text { diandalkan apabila } \\
\text { terdapat bukti bahwa } \\
\text { telah terjadi } \\
\text { perpindahan hak dan } \\
\text { kepemilikan secara } \\
\text { penguasaan and a } \\
\text { hukum. }\end{array}$ & Sesuai \\
\hline
\end{tabular}


Tabel 2 menyajikan perbandingan Pengukuran Aset Tetap oleh BPKAD Kota Manado dengan PSAP No. 07

Tabel 2. Perbandingan Pengukuran Aset Tetap oleh BPKAD Kota Manado dengan PSAP No. 07

\begin{tabular}{|c|c|c|c|}
\hline & PSAP No. 07 & BPKAD Kota Manado & Keterangan \\
\hline & $\begin{array}{l}\text { Aset tetap dinilai } \\
\text { dengan biaya } \\
\text { perolehan. Apabila } \\
\text { penilaian aset tetap } \\
\text { dengan biaya } \\
\text { perolehan tidak } \\
\text { memungkinkan } \\
\text { maka nilai aset } \\
\text { tetap didasarkan } \\
\text { pada nilai wajar } \\
\text { pada saat } \\
\text { perolehan. }\end{array}$ & $\begin{array}{llr}\text { a. } & \text { Tanah diakui pertama } \\
\text { kali sebesar biaya } \\
\text { perolehan } \\
\text { b. Peralatan dan mesin } \\
\text { dinilai dengan biaya } \\
\text { perolehan atau nilai } \\
\text { wajar pada saat aset } \\
\text { tetap tersebut diperoleh } \\
\text { c. Gedung dan bangunan } \\
\text { dinilai dengan biaya } \\
\text { perolehan }\end{array}$ & Sesuai \\
\hline b. & $\begin{array}{l}\text { Biaya perolehan } \\
\text { suatu aset tetap } \\
\text { terdiri dari harga } \\
\text { belinya termasuk } \\
\text { bea impor dan } \\
\text { setiap biaya yang } \\
\text { dapat diatribusikan } \\
\text { secara langsung }\end{array}$ & 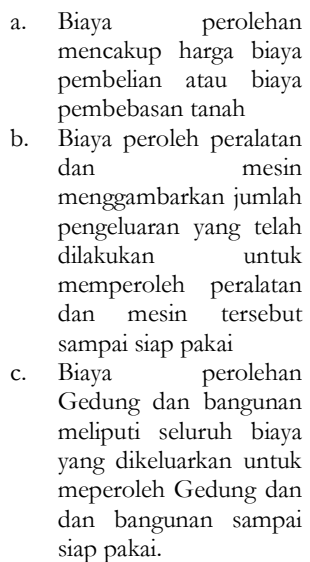 & Sesuai \\
\hline
\end{tabular}

Tabel 3 menyajikan perbandingan Pengungkapan Aset Tetap oleh BPKAD Kota Manado dengan PSAP No. 07.
Tabel 3. Perbandingan Pengungkapan Aset Tetap oleh BPKAD Kota Manado dengan PSAP No. 07

\begin{tabular}{|c|c|c|}
\hline PSAP No. 07 & BPKAD Kota Manado & Keterangan \\
\hline $\begin{array}{l}\text { Laporan keuangan } \\
\text { harus } \\
\text { mengungkapkan } \\
\text { dasar penilaian } \\
\text { yang digunakan } \\
\text { untuk menentukan } \\
\text { nilai tercatat. }\end{array}$ & $\begin{array}{l}\text { a. } \begin{array}{l}\text { Aset tetap tanah } \\
\text { disajikan di dalam }\end{array} \\
\text { neraca sesui dengan } \\
\text { biaya perolehan atau } \\
\text { sebesar nilai wajar pada } \\
\text { saat tanah tersebut } \\
\text { diperoleh. } \\
\text { b. Peralatan dan mesin } \\
\text { disajikan di neraca } \\
\text { dalam kelompok aset } \\
\text { tetap sebesar biaya } \\
\text { perolehannya atau nilai } \\
\text { wajar pada saat } \\
\text { perolehan. } \\
\text { Gedung dan bangunan } \\
\text { disajikan di neraca } \\
\text { dalam kelompok aset } \\
\text { tetap sebesar biaya } \\
\text { perolehannya atau nilai } \\
\text { wajar saat perolehan }\end{array}$ & Sesuai \\
\hline
\end{tabular}

$\begin{array}{lr}\text { b. Setiap jenis } & \text { aset } \\ \text { seperti } & \text { tanah, } \\ \text { gedung } & \text { dan } \\ \text { bangunan, } & \\ \text { peralatan } & \text { dan } \\ \text { mesin dan } & \text { lain } \\ \text { sebagainya } & \text { harus } \\ \text { dinyatakan } & \text { dalam } \\ \text { neraca } & \text { secara } \\ \text { terpisah } & \text { atau } \\ \text { terperinci } & \text { dalam } \\ \text { catatan } & \text { atas } \\ \text { laporan keuangan. }\end{array}$

a. Aset tanah dinyatakan di dalam neraca kelompok aset tetap biaya perolehan tanah tersebut diperoleh

b. Peralatan dan mesin dinyatakan dalam neraca kelompok aset tetap biaya perolehan peralatan dan mesin tersebut diperoleh

c. Gedung dan bangunan dinyatakan dalam neraca kelompok aset tetap biaya perolehan Gedung dan bangunan tersebut diperoleh

c. Rekonsiliasi jumlah tercatat pada awal dan akhir periode yang menunjukkan penambahan, pelepasan, akumulasi

penyusutan dan perubahan nilai jika ada mutasi aset tetap lainnya.

Sesuai

a. Rekonsiliasi tercatat tanah pada awal dan akhir periode yang menunjukkan penambahan, perolehan dan pengurangan.

b. Rekonsiliasi nilai tercatat peralatan dan mesin pada awal dan menunjukkan akhir periode yang

penambahan, perolehan yang bersal dari pembelian dan pengurangan.

c. Rekonsiliasi nilai tercatat Gedung dan bangunan pada awal dan akhir periode yang menunjukkan penambahan, perolehan yang bersal dari pembelian dan pengurangan.

(Sumber: Data Olahan, 2019)

\section{Kesimpulan dan saran Kesimpulan}

Berdasarkan hasil penelitian dan pembahasan yang telah dilakukan, maka dapat disimpulkan sebagai berikut :

1. Pengakuan aset tetap pada BPK-AD

Kota Manado telah sesuai dengan SAP No. 07. 
2. Pengukuran/Penilaian suatu aset tetap pada BPK-AD Kota Manado telah sesuai dengan SAP No.07.

3. Pengungkapan aset tetap pada BPK-AD Kota Manado sudah sesuai dengan SAP No. 07.

4. Pada BPK-AD Kota Manado dalam pengelolaan aset daerahnya mengikuti penyajian tersendiri yang dibuat oleh BPK-AD kota Manado yaitu Buletin Teknis (Bultek) sebagai acuan guna mengatur dan menyesuaikan pengelolaan aset daerah sesuai dengan SAP No. 07.

\section{Saran}

Berdasarkan hasil penelitian mengenai Apakah perlakuan akuntansi suatu aset tetap di BPK-AD Kota Manado sudah sesuai dengan Standar Akuntansi Pemerintah No. 71 Tahun 2010 Peryataan No. 07, maka berikut saran-saran yang dapat diberikan penulis dalam penelitian ini :

1. BPK-AD kota Manado, agar tetap mempertahankan perlakuan, pengukuran, dan pengakuan aset milik daerah kota Manado.

2. BPK-AD juga perlu mengatasi setiap masalah-masalah yang dihadapi dalam penerapan PP 71 Tahun 2010 agar bisa seutuhnya sesuai dengan PP 71 Tahun 2010.

\section{Daftar pustaka}

Halim, A., \& Kusufi, S. (2013). Akuntansi Sektor Publik Akuntansi Keungan Daerah. Edisi Keempat. Jakarta. Salemba Empat.

Hariadi, M., Nangoi, G. B., \& Wangkar, A. (2018). Evaluasi Penerapan Perlakuan Akuntansi Terhadap Aktiva Tetap Berdasarkan PSAK No.16 Pada PT Pegadaian (PERSERO) Cabang Malalayang Manado. Going Concern: Jurnal Riset Akuntansi. 13(02).https://ejournal.unsrat.ac.id/index.php/g c/article/view/19194

Kieso., Donald., Jerry, J., Weygandt., \& Warfield, D. (2016). Intermediate Accounting. 16 th $^{\text {th }}$ Edition. New York

KSAP. (2010). Buletin Teknis Standar Akuntansi Pemerintah No.09 Tentang Aset Tetap. Jakarta.

Mahsun. (2013). Akuntansi Sektor Publik. Edisi Ketiga. Yogyakarta. BPFF.

Masipuang. Y., Ilat, V., \& Pinatik, S. (2015). Analisis Perlakuan Akuntansi Aset Tetap Pada Badan Kepegwaian Dan Diklat Kota Manado. Journal GOING CONCERN. 10(03), 45-55. https://doi.org/10.32400/gc.10.3.8444.2015
Nordiawan, D., Putra, I., \& Rahmawati, M. (2012). Akuntansi Pemerintahan. Jakarta: Salemba Empat.

Peraturan Menteri Dalam Negeri Nomor 19 Tahun 2016 Tentang Pedoman Pengelolaan Barang Milik Daerah. Jakarta.

Peraturan Pemerintah Nomor 58 Tahun 2005. Pengelolaan Keuangan Daerah. Jakarta.

Peraturan Pemerintah Republik Indonesia Nomor 71 tahun 2010. Standar Akuntansi Pemerintahan.

Putra. T. M. (2013). Analisis Penerapan Akuntansi Aset Tetap Pada CV. Kombos Manado. Jurnal Riset Ekonomi, Manajemen, Bisnis dan Akuntansi. 1(3) https://ejournal.unsrat.ac.id/index.php/emba/is sue/view/362

Sugiyono. (2009). Metode Penelitian Bisnis. Bandung: Alfabeta.

Surya, R. A. S. (2012). Akuntansi Keuangan Versi IFRS.Edisi Pertama. Yogyakarta: Graha Ilmu.

Tanjung, A. H. (2013). Akuntansi Pemerintahan Daerah Berbasis Akrual, Cetakan Kedua. Bandung: Alfabeta.

Undang-Undang Republik Indonesia Nomor 23 Tahun 2014 Tentang Pemerintahan Daerah. Jakarta 